TURIZAM

Volume 22, Issue 4

$168-180(2018)$

ORIGINAL

SCIENTIFIC PAPER

\title{
Frankfurt Table as an Example of Good Practices of Business Ethics in Tourism
}

\author{
Ljubica Jurisin ${ }^{A}$, Aleksandra S. Dragin ${ }^{A}$, Tatjana Pivac ${ }^{A}$, Kristina Kosic ${ }^{A}$, Ivana Blesic ${ }^{A}$ \\ Received: December 2018 | Accepted: January 2019 \\ DOI: 10.5937/turizam22-20635
}

\begin{abstract}
The purpose of this paper was to analyse the Frankfurt Table, as a successful tool in development of business ethics in global tourism. The aim of the research was to examine the form and the usage of the Frankfurt Table and to determinate the situation in Serbia, in terms of whether this list is used as a guide in the business of travel agencies. In this regard, the attitudes of the employees in travel agencies in Serbia were examined. During the data collection and analysis, as well as during the interpretation of the results, historical, comparative, descriptive methods, as well as the survey research and synthesis were used. The research results can be useful for tourism industry, including the numerous participants whose services are part of the tourist arrangement.
\end{abstract}

Keywords: Frankfurt Table, tourism, travel agencies, Serbia

\section{Introduction}

The product of the tour operator (travel agency) is based on the promise that the client will, experience and see everything that he/she was thinking and expecting from a holiday. Since purchasing a holiday is based on the trust that consumer gives to the travel agency by purchasing its product, the travel agency is obliged to take care of the interests and desires of its customers, and in that way, it might protect the personal interest at the same time. Since each individual has different expectations in terms of the leisure and everyone perceives experience during the holiday in a different way, it is clear that travel agencies have ungrateful role in the entire operation (Cavlek, 1998).

With development of business related to travels, the concept of protecting the users of the package arrangement was gradually developed. The protection of the interests of tourist consumers went in direction of extending the obligations of tour operators towards them. The reason was related to the fact that the travel agencies tried to minimize their obligations towards the clients, and they were trying to eliminate any responsibility regarding the failures of the arrangements by shifting the responsibility and the guilt to the various service providers. Also,

A University of Novi Sad, Faculty of Sciences, Department of Geography, Tourism and Hotel Management, Trg Dositeja Obradovića 3, 21000 Novi Sad, Serbia; Corresponding author: aleksandra.dragin@dgt.uns.ac.rs 
since the assessment of the quality of services is a subjective category, the tour operators have tried to reject many complaints as groundless (Cavlek, 1998). This is still happening, so the question is in which manner the tourist can be protected from it.

Without going into the details of legal regulation and procedure for the protection of tourists in certain countries, it should be emphasized that this protection is complex and that it can be thoroughly regulated and efficient, which is confirmed by developed emissive tourist markets, most often in the following way:

- Within the scope of the state, through the state legislation and consumer protection authorities;

- In the scope of the profession of the tour operator, by special regulations for consumer protection, quality assurance for provided services, i.e. codes of conduct issued by the tour operators themselves, members of the tour operator's trade union and

- In the scope of the consumers, through the different consumer associations and special sections in the media (Jurisin, 2015).

The number of tourists who travel by pre-formed package arrangement has been increasing in the recent years. However, the holidays in the other countries and complex travels to the various parts of the world might have significant risk for tourists, unless the travel agency that made the arrangement, provides everything the tourist paid for in a professional way, including the full safety during the travel and holidays. Because of that, in some countries there are prescribed laws which in different ways regulate the legal relations between the consumers and the travel agency. Considering the fact that organizers of tourist trips in certain countries have a different level of responsibility towards their clients, and that the sale and offer of the package arrangements are differently legally regulated, in order to protect this growing segment of consumers in the market, the European Union has just initiated the need to unify the laws, regulations and administrative provisions within the member states that relate to the offer and sale of the package arrangements in the territory of the European Union. The EU guidelines on travel in package arrangements have obliged all of the EU members to implement a number of regulations in their national legislation. The aim of the Guidelines is to improve the quality of services in all segments of the tourist offer and the organization of tourist trips, but also to make strict demands for travel agencies related to the implementation of the contract regarding the sale of package arrangements and providing the financial guarantees for repayment of paid money to clients in the case of insolvency of travel agencies. The mentioned guidelines prescribed high standards for the protection of tourists; thereby establishing the completely new relations between the tour operator and the consumer. Tour operators are considered as responsible for: incomplete holiday, physical injuries of their clients on the journey or during the holiday, as well as the damage to the client's property. It means that responsibility of contracted services cannot be transferred to the other participants - hotels, carriers, etc. Therefore, all of those who provide tourist services started to make precise contracts in order to protect themselves from claims for damages, which contributed to the increase in the quality of tourist services in general (Ateljevic, 2010). On the other hand, tour operators are relieved of these responsibilities only if they are results of the emergence of "force majeure" and in the case when unwanted circumstances can be connected neither to the tour operator, nor to any of his service providers.

It is certain that those organizations that do not want to accept the EU regulations and standards will not be able to compete successfully on the market simply because consumers will seek the standards and protection afforded by the European Union (Jurisin, 2015). 
In Germany, but also in the other European countries, the most mentioned is so-called Frankfurt Table (or the Frankfurt orientation list of deficiencies/faults), while the daily newspapers sometimes write about it in the peak of the tourist season (www.monitor.hr/clanci/ frankfurtska-tablica-odsteta-nocna-mora-turistickih-zemalja/13925/; www.glasistre.hr/vijesti/arhiva/kako-naplatiti-propalo-putovanje-341568). What is it about, and to what extent the problem is present and regulated in Serbia, are the main issues that have induced this research?

\section{The Frankfurt Table}

The Frankfurt Table or the Frankfurt orientation table of failures (in the original "Frankfurter-Tabelle") is a list of the most common failures in the execution of a contract between the tour operator and the client with a certain percentage of compensation that in such cases the tour operator is required to pay to the client in relation to the amount of the paid arrangement. The document was drafted by a state court in Frankfurt, more precisely the 24th Chamber of the Provincial Court, following its practice in resolving such disputes. Namely, in Frankfurt there are the headquarters of TUI, one of the largest European tour operators, that was faced with a large number of tourists' complaints. To prevent the issues related to providing the different compensations for the same thing, the court made a table with a list of possible failures in travel that appeared in practice and with the amount of compensation in percentage for each case. This table was created in mid-1985, when it was first published, in the journal Neue Juristische Vochenschrift (Suleic et al., 2015). The base of the table has been used since 1985, and it is periodically updated.

The Frankfurt table is the result of the cooperation of the Frankfurt Court and tourism experts. The table is also a guide in the business of travel agencies. It is not binding for the court, because every case is resolved depending on particular circumstances. However, the resolution of many cases is based on the principles of the Frankfurt table. In addition to German, Austrian courts also respect the principles of the Frankfurt table, but the Austrian courts are re-considering it because of the price reduction, that arises from the travel failures (Dragicevic, 2010).

It can be said for the Frankfurt table that it is a list of all verdicts in tourism. It is not an official list, nor a legal document, nor it is binding for courts and tour operators/travel agencies. It represents a guide and public opinion on the amount of compensation and the type of failures. The table became popular especially after the unification of Germany, when the eastern Germans wanted to get closer to western Germans on travels, so they often complained (www.glasistre.hr/vijesti/arhiva/kako-naplatiti-propalo-putovanje-341568).

According to the type, all of the failures are grouped in the following way: accommodation, food, transportation and more. Each group contains a list of the failures (which are changing according to the practice), indicating the percentage of compensation and observations that should be considered in the appeal process.

In our country, it is not customary to draw up individual contracts for travellers with special requirements, but if there are such requests, they are added to the basic travel contract, and in that way the agency is obliged to implement them. Our tourists do not have the custom to ask for financial compensation for most of the failures included in the Frankfurt Table, but they will usually only complain to the travel agency upon returning from the trip.

From the above mentioned it can be observed that the Frankfurt Table is not used in our country, most likely due to the ignorance and lacking of the interest of domestic tourists, who seek for the compensation only for not fulfilling the most important contractual obligations, 
and they sue the agency only in the most extreme cases. There is also the possibility that the passengers do not believe in the legal system in our country and that it is one of the reasons why they do not file the complaints.

\section{Methodology}

During the collecting and analysis, the obtained data, but also throughout the interpretation of the results, historical, comparative, descriptive methods, as well as the survey research and synthesis were used.

One of the tasks of this paper was to research to what extent the Frankfurt Table is used within the travel agencies, i.e. by the tour operators in Serbia. In this regard, the task was accomplished through researching whether the travel agencies were familiar with the term "Frankfurt Table" and whether they used it as a manual in their business.

The survey was conducted in 2015. Questionnaires were sent to electronic addresses of 100 travel agencies. The answers were sent by 29 agencies: 12 from Belgrade, 5 from Novi Sad, 4 from Kragujevac, 1 from Valjevo, Zrenjanin, Nis, Zemun, Sabac, Bela Crkva and Sremska Mitrovica.

The survey included two close-type questions: Is your agency aware of the Frankfurt Table of failures? Does your agency apply its business rules? Distribution of the frequency of the respondents' answers is represented in Graphs 1 and 2. In the last part of the survey, respondents were allowed to give additional explanation (comment) on the application of the principles of the Frankfurt Table in their business.

\section{Research results}

Everything that a tourist brochure describes or displays with photograph is a required part of the promised package arrangements. The tour operators must, regardless of whether they are responsible for the failures or not, stand behind the promised services. If services are not provided in the promised form, they could be considered as failures, and the travellers thus have the right to refer to the guarantee given by the agency (www.verbraucherrecht.at/development/typo/test/fileadmin/downloads/ FrankfurterListe/Frankfurter_Liste_zur_Reisepreisminderung.pdf).

The fee of the compensation according to the Frankfurt Table includes:

- Compensation, which is a fee equal to the difference between the paid and received services,

- Compensation for the "lost satisfaction" because the client did not receive what he paid for, and for this reason, he was denied the expected satisfaction. However, a client may be deprived of satisfaction not only because of something he was specifically charged for, but also because of something that is assumed that a client should receive (for example, a clean room), or it is something promised by a description in a brochure, and the client did not receive it (closeness to the beach, the possibility of swimming in the sea, etc.).

The amount of compensation that can be paid to the client in each of the mentioned groups of the main services is limited by specific percentage (Cavlek, 1998). 
Table 1. Frankfurt table-accommodation

\begin{tabular}{|c|c|c|}
\hline Failure & $\%$ & Comment \\
\hline 1. Deviation from the reserved accommodation & $10-25$ & Depending on the distance \\
\hline $\begin{array}{l}\text { 2. Deviation from the position in the settlement } \\
\text { (distance from the beach) }\end{array}$ & $5-15$ & - \\
\hline $\begin{array}{l}\text { 3. Deviation from the type of the accommodation within the } \\
\text { reserved hotel (hotel instead of the bungalows, unwanted floor) }\end{array}$ & $5-10$ & - \\
\hline $\begin{array}{l}\text { 4. Deviation from the type of the room } \\
\text { a. Double instead of single } \\
\text { b. Triple instead of single } \\
\text { c. Triple instead of double } \\
\text { d. Quadruple instead of double }\end{array}$ & $\begin{array}{c}20 \\
25 \\
20-25 \\
20-30\end{array}$ & $\begin{array}{l}- \\
-\quad- \\
\text { - Decisive factor is whether the people from } \\
\text { the same reservation or unknown travellers } \\
\text { are in the same accommodation }\end{array}$ \\
\hline $\begin{array}{l}\text { 5. Lack of the equipment in the room } \\
\text { a. It is too small } \\
\text { b. There is no balcony } \\
\text { c. The lack of the sea view } \\
\text { d. The lack of the (personal) bathroom/toilet } \\
\text { e. The lack of the (personal) toilet } \\
\text { f. The lack of the (personal) shower } \\
\text { g. The lack of the air conditioning } \\
\text { h. The lack of the radio/TV set } \\
\text { i. Too little furniture and equipment } \\
\text { j. Damage (cracks, humidity, etc.) } \\
\text { k. Animal pests (e.g. rats) }\end{array}$ & $\begin{array}{c}5-10 \\
5-10 \\
5-10 \\
15-25 \\
15 \\
10 \\
10-20 \\
5 \\
5-15 \\
10-50 \\
10-50\end{array}$ & $\begin{array}{l}\text { - If it was promised/depending on the season } \\
\text { - If it was promised } \\
\text { - } \text { In the case of reservation } \\
\text { - In the case of reservation } \\
-\quad \text { In the case of reservation/depending on } \\
\text { the season } \\
\text { - If it was promised } \\
- \\
-\end{array}$ \\
\hline $\begin{array}{l}\text { 6. Device failure } \\
\text { a. Toilet } \\
\text { b. Bathroom/hot water boiler } \\
\text { c. Lack of the electricity/lack of the gas } \\
\text { d. Water } \\
\text { e. Air conditioning } \\
\text { f. Lift }\end{array}$ & $\begin{array}{c}15 \\
15 \\
10-20 \\
10 \\
10-20 \\
5-10\end{array}$ & $\begin{array}{c}- \\
- \\
- \\
- \\
-\quad \text { Depending on the season } \\
- \text { Depending on the floor }\end{array}$ \\
\hline $\begin{array}{l}\text { 7. Maintenance } \\
\text { a. Complete absence } \\
\text { b. Poor cleaning } \\
\text { c. Insufficient frequency of changing the linen and the towels }\end{array}$ & $\begin{array}{c}25 \\
10-20 \\
5-10\end{array}$ & $\begin{array}{l}- \\
-\end{array}$ \\
\hline $\begin{array}{l}\text { 8. Disturbances } \\
\text { a. Noise during the day } \\
\text { b. Noise during the night } \\
\text { c. Stink }\end{array}$ & $\begin{array}{c}5-25 \\
10-40 \\
5-15\end{array}$ & $\begin{array}{l}- \\
- \\
-\end{array}$ \\
\hline $\begin{array}{l}\text { 9. Lack of the (promised) spa facilities } \\
\text { (thermal baths, massage) }\end{array}$ & $20-40$ & $\begin{array}{l}\text { - Depending on the type of promised facility } \\
\text { (e.g. spa tourism) }\end{array}$ \\
\hline
\end{tabular}

Source: www.rechtspraxis.de/frankfurt.htm

The first thing a tourist has to do when he sees the failures is to require their improvement on the spot. For example, hotel can meet the needs of tourist by providing him an adequate room and thereby save his holiday, without additional expenses for tourists.

When the failures cannot be removed (there is no sandy beach), then evidence should be provided: photographs and videos (noisy machines), names and addresses (with numbers and e-mails) of the people who suffered the damage, including the written confirmation from the tour guide that the failures have not been adequately removed (www.verbraucherrecht.at/ development/typo/test/fileadmin/downloads/FrankfurterListe/Frankfurter_Liste_zur_Reisepreisminderung.pdf). 
Upon returning from a trip, a tourist may seek a price reduction or a refund from the tour operators. The traveller should (in registered letter) indicate the failures and determine the amount that he requests to be refunded.

A tourist can use the Frankfurt table to discover how much money he can claim for possible failures. Frankfurt table includes percentages that Frankfurt's court finds appropriate for typical tourist failures. However, neither the courts nor the tour operators are obliged to pay the compensation strictly according to percentages from the table. In some cases, when no settlement occurs outside the court, the case is referred to the competent court. Tour operators or their subagents, due to unsuccessfully accomplished travel, issue a guarantee to cover the compensation of damage. For example, if food in the hotel caused stomach problems and necessary rest, instead of enjoying the holiday, then tourist has the right to seek the compensation for medical expenses, including the pain and suffering. In such cases, it is important to provide comprehensive documentation of the seriousness of the disease (all of the passengers in the system) and documentation of one's own disease (doctor's certificate).

Since January 1st, 2004 there is a fee, which can be charged due to non-pecuniary damage. When a trip is completely or largely shaken, the lack of enjoyment on the holiday can be compensated in cash in Austria. This is a partial remuneration which can amount 50-70 € per person.

Guarantee requests have to be made within the two years after returning from the trip. Within three years after the verdict has been rendered, the damage has to be reimbursed. It is advisable for the complaints to be resolved as quickly as possible. (www.verbraucherrecht.at/ development/typo/test/fileadmin/downloads/FrankfurterListe/Frankfurter_Liste_zur_Reisepreisminderung.pdf).

Table 1 shows failures in the equipment of accommodation. In addition to the equipment of the room, the following defects are also identified in the accommodation: the quality of utility services (water supply, hot water for bathing, gas supply, etc.), hygiene, poor cleaning, inadequate bedding, towels, noise during the day or night night, smell, etc. Thus, the price of the arrangement can be reduced from $5 \%$ to $50 \%$ depending on the lack of the accommodation.

Table 2 and 3. Frankfurt table-Food and Transportation

\begin{tabular}{|l|c|c|}
\hline Failure -FOOD & $\%$ & Comment \\
\hline 1. Complete absence & 50 & - \\
\hline 2. Content disadvantages & 5 & \\
a. Uniform meals & 10 & \\
b. Insufficiently warm meals & $20-30$ & - \\
c. Spoiled meals & & \\
\hline 3. Services & $10-15$ & \\
a. Self-service & $5-15$ & \\
b. Long waiting & 10 & \\
c. Eating in shifts & $5-15$ & If promised \\
d. Dirty tables & $10-15$ & \\
e. Dirty cutlery and dishes & $5-10$ & \\
\hline 4. Lack of the air conditioning in the dining room & & \\
\hline
\end{tabular}




\begin{tabular}{|c|c|c|}
\hline Failure - TRANSPORTATION & $\%$ & Comment \\
\hline 1. Rescheduled flight for more than four hours & $\begin{array}{l}1 / 5 \text { of the price per day for each } \\
\text { next hour }\end{array}$ & \\
\hline $\begin{array}{l}\text { 2. Defects in the equipment } \\
\text { a. Lower class } \\
\text { b. Great deviations from the standard }\end{array}$ & $\begin{array}{c}10-15 \\
5-10\end{array}$ & - \\
\hline $\begin{array}{l}\text { 3. Service } \\
\text { a. Procurement } \\
\text { b. Lack of the usual fun contents during the flight (radio, } \\
\text { film, etc.) }\end{array}$ & $\begin{array}{l}5 \\
5\end{array}$ & - \\
\hline 4. Change in means of transport & $\begin{array}{c}\text { Part of the travel price related to } \\
\text { delay in transport }\end{array}$ & \\
\hline $\begin{array}{l}\text { 5. Lack of the transport from the airport (rail station) } \\
\text { to the hotel }\end{array}$ & $\begin{array}{l}\text { The cost of a substitute means of } \\
\text { transport, taxi for example }\end{array}$ & \\
\hline
\end{tabular}

Source: www.rechtspraxis.de/frankfurt.htm

The most common failures in the diet are: monotonous or not enough warm meals, tasteless food, self-service (instead of the waiters), dirty table, eating in the shifts, dirty dishes/cutlery and the lack of the air conditioning in the dining room. The guest can claim the damages even if the menu is monotonous, up to $5 \%$, and up to $15 \%$ if there is no waiter, if clients are waiting for food for a long time or if the dishes are dirty (Table 2). When it comes to the transportation to a destination, tourist can complain about a lower class of transportation, but also on a poor service in a vehicle (Table 2).

Table 4 and 5. Frankfurt table - The other

\begin{tabular}{|c|c|c|}
\hline Failure & $\%$ & Comment \\
\hline 1. No pool or dirty pool & $10-20$ & In case of a promise \\
\hline $\begin{array}{l}\text { 2. No indoor pool } \\
\text { a. With an existing outdoor pool } \\
\text { b. With a non-existing outdoor pool }\end{array}$ & $\begin{array}{l}10 \\
20\end{array}$ & $\begin{array}{l}\text { - In case of a promise } \\
\text { - If it can be used for the season }\end{array}$ \\
\hline 3. No saunas & 5 & In case of a promise \\
\hline 4. Lack of the tennis court & $5-10$ & In case of a promise \\
\hline 5. No mini golf court & $3-5$ & In case of a promise \\
\hline 6. Lack of the school of sailing, surfing, diving & $5-10$ & In case of a promise \\
\hline 7. No riding opportunities & $5-10$ & In case of a promise \\
\hline 8. Lack of the child care service & $5-10$ & In case of a promise \\
\hline 9. Inability to swim in the sea & $10-20$ & $\begin{array}{l}\text { Depending on the description in the } \\
\text { brochure and possible reasonable } \\
\text { alternatives }\end{array}$ \\
\hline 10. Dirty beach & $10-20$ & - \\
\hline 11. Lack of the deckchairs, umbrellas & $5-10$ & In case of a promise \\
\hline 12. Lack of the bistro or the bar on the beach & $0-5$ & $\begin{array}{l}\text { Depending on the possible } \\
\text { alternatives }\end{array}$ \\
\hline 13. Lack of the nudist beach & $10-20$ & In case of a promise \\
\hline $\begin{array}{l}\text { 14. No restaurant or supermarket } \\
\text { a. Beside the meals in the hotel } \\
\text { b. Beside the meals in your own arrangement }\end{array}$ & $\begin{array}{c}0-5 \\
10-20\end{array}$ & $\begin{array}{l}\text { In case of a promise/depending on } \\
\text { the possible alternatives }\end{array}$ \\
\hline
\end{tabular}




\begin{tabular}{|c|c|c|}
\hline Failure & $\%$ & Comment \\
\hline $\begin{array}{l}\text { 15. No place for entertainment } \\
\text { (disco, nightclub, cinema, animators) }\end{array}$ & $5-15$ & In case of a promise \\
\hline 16. Lack of the boutique or the street with shops & $0-5$ & $\begin{array}{l}\text { Depending on the possible } \\
\text { alternatives }\end{array}$ \\
\hline 17. No trips to land during the cruise & $20-30$ & $\begin{array}{l}\text { Part of the trip price per day of } \\
\text { excursion to the mainland }\end{array}$ \\
\hline $\begin{array}{l}\text { 18. Lack of the travel guidance } \\
\text { a. Only organization } \\
\text { b. When travelling with special sights } \\
\text { c. On study trips with professional guidance }\end{array}$ & $\begin{array}{c}0-5 \\
10-20 \\
20-30\end{array}$ & $\begin{array}{c}- \\
- \\
-\quad \text { In case of a promise }\end{array}$ \\
\hline $\begin{array}{l}\text { 19. Loss of the time due to the necessary relocation } \\
\text { a. Inside the same hotel } \\
\text { b. To another hotel }\end{array}$ & $\begin{array}{l}\text { - Part of the price for } 1 / 2 \text { days } \\
\text { - Part of the price for } 1 \text { day }\end{array}$ & \\
\hline
\end{tabular}

Source: www.rechtspraxis.de/frankfurt.htm

In the fourth group (Table 3) the possible failures that were mentioned are the most numerous and diverse. There were the cases where tourists demanded the money from the agencies because there were no sun-umbrellas and deck chairs on the beach (www.glasistre.hr/vijesti/arhiva/kako-naplatiti-propalo-putovanje-341568). Complaints can also be made by guests if in a place where they reserved accommodation there is no shopping street, entertainment or night life.

In addition to the table, part of the document are "Notes", in which it is more closely explained on which part of the price, duration of the arrangement or person (for example the special characteristics or difficulties of the traveller) is applied the percentage reduction.

\section{Travel law in Germany}

Sometimes the joy because of the free days in a year is as big as a disappointment when the paid holiday does not meet the expectations. The result of that is often a dispute with the tour operator that deals with the price reduction or claiming the compensation, especially in Germany, where travel outside the territorial boundaries is raising.

On the website of the law office "Advoprax AG", specialized in the travel law, the main areas of tourist law are explained in detail(www.advoprax.de/neu/rechtsinformationen/reiserecht).

The information in the catalogue should be legible, accurate, clear and complete. First of all, information should be printed where a passenger can expect them. The catalogue should contain information on the following elements: travel price, information on possible payment, payment deadline for the rest of the amount.

Depending on whether they are relevant, the following elements should be included: the place, the means of transport (class and properties), accommodation (type, category, location...), accommodation properties, evaluation of accommodation, meals, travel routes, visa information, the number of travellers required for the travel.

The tour operator is responsible for the information in the catalogue. Claims raised due to insufficiently careful reading of the catalogue are invalid.

Information concerning the situation in particular country is not mandatory, however their presence is recommended.

Particular attention should be paid to information on certain restrictions. The failures listed in the catalogue cannot be the basis for price reduction requests. Also, consideration should 
be given to different terms of deviation from the contract as well as related costs, passenger obligations, liability and deadlines. In this way, tourists will be protected from unpleasant surprises.

The tour organizer is thus obliged to eliminate all of the failures. If the tour operator fails to provide assistance within the appropriate time limit, or if he does not want to help, the traveller may request a reimbursement of the costs.

In the case of complaints, attention should be paid to the following points:

Complaints to hotels are not enough. It is necessary to contact the tour organizer. If personal contact is not possible, telephone contact with the agency in Germany should be established.

The failures should be accurately described to the tour guide and compensation should be requested. Define a deadline for the compensation.

A witness - you should have a witness during the conversation with the tour guide. It is the best to be the second guest of the hotel, who is not related to the passenger who complains.

Protocol - you should request a protocol to be made about the conversation. There is no legal obligation on the protocol. Still, it is the best to look for the protocol immediately, not just at the end of the trip.

A written confirmation regarding the fact that your claim is taken into the consideration you should request this confirmation from the tour operator. A written certificate confirming the failures is not mandatory.

Compensation of the failures - the proposed compensation of failures should be indicated in the protocol.

Deviation from the contract - there is a possibility that the passenger would completely abandon the journey or temporarily interrupt it. When such deviation from the contract is justified, there is a possibility that the court would not accept the deviation from the contract and that the full amount would have to be paid.

Independent search for the accommodation - if defects of the hotel are large, there is a possibility for the tourist himself to search for adequate accommodation. In that case there is a risk that the court would not represent the same opinion as a tourist and that the price of the hotel would have to be paid.

Determination of the deadline in written - it is necessary for the tourist to determine the deadline for the compensation in written.

In order to be able to seek the compensation in the court, it is necessary for the tourist to prove the failures. Attention should be paid to the following points:

Evidence - photographs, videos, addresses of the witnesses, hotel catalogues, as well as description of failures.

The choice of the witness - family members and friends do not have much credibility in front of the court. This fact should be taken into the consideration.

Witness statements - witnesses should confirm the statement of the tourist. Everything contained in the statement is valid if the witnesses saw or heard it. For example, a testimony regarding the room defects would not be accepted if the witness himself did not see those defects.

Foreign witnesses - testimony of the foreigners in front of the German courts is problematic because it can delay the trial.

If the passenger submits an application for compensation after returning from the trip, attention should be paid to the following points:

Deadline - requests must be submitted no later than one month after returning from the trip (according to the date of returning, specified in the contract). Within the stated deadline, the complaint has to be submitted to the tour organizer. 
Form of complaint - written form is not mandatory, but it is strictly recommended.

Content of the complaint - all of the failures should be described in detail. Failures noted after the deadline are not accepted.

Signature - the complaint should be signed by all of the involved people. If it is a group complaint, authorization is required by all participants.

Assigning a certain value to requirements - each claim should be applied to a certain amount of the money.

Engagement of the lawyer - in order to prevent mistakes, it is recommended to hire the lawyer (Jurisin, 2015).

Reduction of the price is only considered if the failures are responsibility of the tour operator and if they are not in agreement with the contract. For example, a car accident with a third person is not a basis for reducing the price. Also, one should bear in mind that different criteria are applied for the cheap and the luxury travel.

In minor failures, the price reduction is not unauthorized (for example if the colour of the hotel's facade is different from the actual colour in the catalogue). Also, the experience shows that the opinions of the tour operators and tourists often differ in terms of the corresponding price reduction. In such cases, the court usually makes a final decision.

If the failures are large, the passenger is able to withdraw from the contract and to claim the compensation, which can mean full refund of the paid funds. It is possible that the travel cost is reduced up to $100 \%$.

There are no rules regarding the determination of the adequate price reduction. However, there are guidelines, i.e. already mentioned table issued by the court in Frankfurt.

In addition to reducing the travel costs, the traveller is sometimes entitled to claim the compensation for the lack of the "joy of the holiday". Such compensation may be required if the holiday was ruined to the tourist, in addition to the failures of the travel. If the trip was completely ruined, the traveller has the right to claim a monetary compensation (www.advoprax. $\mathrm{de} / \mathrm{neu} /$ rechtsinformationen/reiserecht; Jurisin, 2015).

\section{Travel law in Serbia and the attitudes of the employees in travel agencies in Serbia on the Frankfurt table}

In Serbia, there is a whole set of laws, accompanying regulations and codified business customs that regulate business relations, obligations and responsibilities of various service providers in tourism (Dragin, 2018). However, the regulations of the Law do not sufficiently raise the awareness of the business participants in tourism about the importance of accepting the responsible and ethical behaviour (Simat et al., 2012; Simat, Dragin, 2012). Then the question arises: what happens in Serbia when tourist does not receive the fully paid services as part of the package arrangement? YUTA explains that the lack of the service will not cause the loss of the license. It is recommended that the passengers protect their rights in two ways: one is addressing the tourist inspection, and the other is addressing the YUTA association, in order to conduct the arbitration procedure. In the YUTA association this arbitration is carried out in accordance with the EU-based procedures, according to the so-called Frankfurt table (www.politika.rs/rubrike/Drustvo/Petnaest-turistickih-agencija-izgubilo-licencu-za-rad. lt.html; www.rts.rs/page/stories/sr/story/125/Dru\%C5\%A1tvo/1363508/ Ko+\%C5\%A1titi+turiste+iz+Srbije.html), related to percentages of compensations for the value of partial execution or non-execution of the Travel Agreement. 
One of the tasks of this paper is to explore to which extent the Frankfurt table is in use in travel agencies, tour operators in Serbia. The survey included the issues which considered: is the specific travel agency aware of the Frankfurt table of failures and does it apply its regulations in its business?

The results are almost uniform in being aware of the Frankfurt table (Graph 1). In the second survey question, the results are slightly different: $62 \%$ of the respondents answered that they do not use, i.e. do not apply the Table in their business, $24 \%$ of them use it partially, while it is applied by $14 \%$ of the respondents (Graph 2).
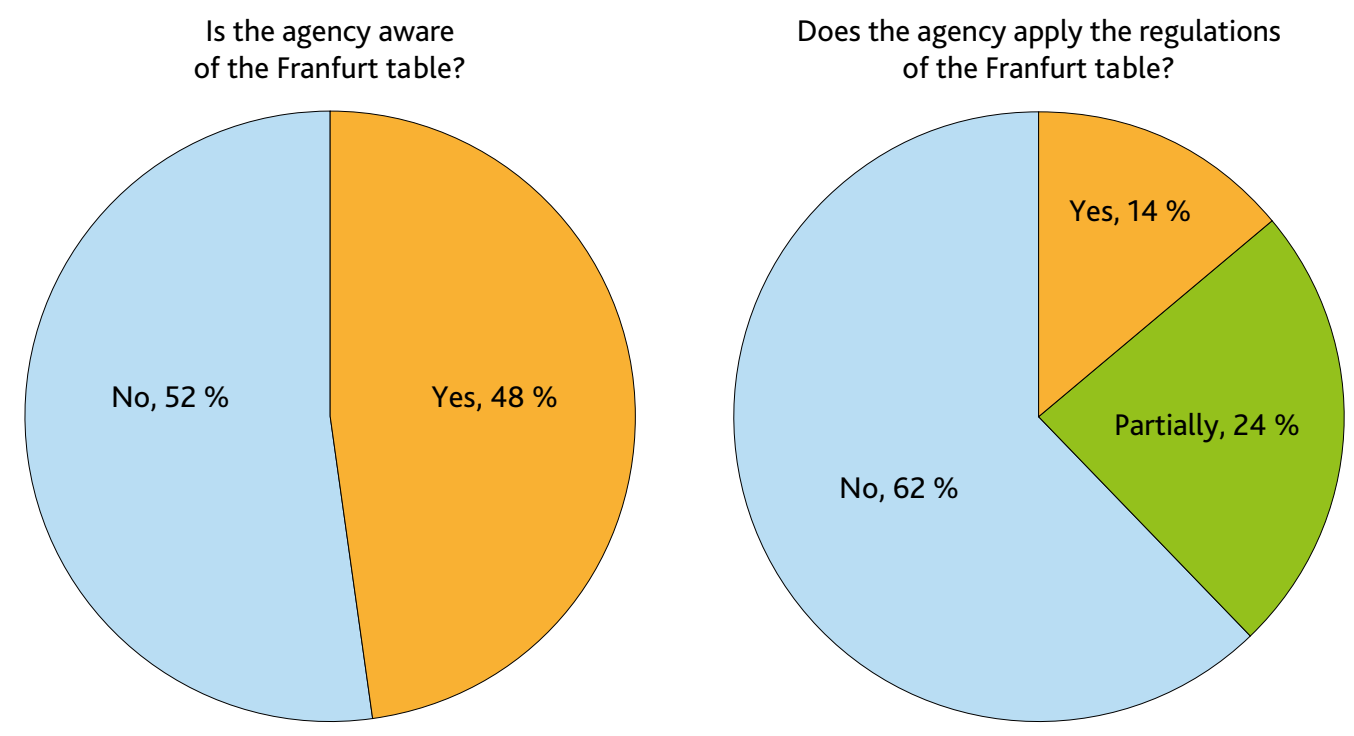

Graphs 1 and 2. Awareness and application of the Frankfurt table in travel agencies in Serbia

Some agencies were not familiar with the term "Frankfurt table", so they asked for additional explanation, in order to be able to use it in the future. Apart from the simple answers with yes or no, some of the respondents provided the further explanation on this subject:

- "I am, of course, as the owner and director, and especially as experienced tourist worker and someone who follows the world trends in the business. I am aware of the concept and details of applying the "Frankfurt table of failures"."

- "The "Frankfurt table of failures" was made by the German State Court, and not by the competent authorities of the Republic of Serbia and relevant Ministry, so it is not an integral part of the legislation and we are not obligated to unconditionally follow its regulations. However, as the Frankfurt table comes from one of the best regulated societies, every experience, legislation, as well as standards or working procedures are welcomed and valuable. For that reason, I can say that in my business, when it comes to the need to compensate a part of the money paid to the unsatisfied passenger due to the failures in the service provided (or some part of it), we partly follow the regulations of the "Frankfurt table offailures"."

- "Bearing in mind that complaints and possible claims for compensation, in a free assessment, represent $0.05 \%$ of the whole numbers of signed contracts (per 10,000 users, 4-6 persons), or annually 2-3 cases, we do not apply the "Frankfurt percentages", but free and flat agreement with the injured party." 
- "The answer to the second question is yes and no. It always depends upon the circumstances. However, in these situations, we must always check all the real circumstances. But in order to avoid any embarrassing situations, we should pay the attention to our subagents."

- "I know what the Frankfurt table is. It was mentioned a lot few years ago when the Law on Tourism was discussed on some meetings in the Serbian Chamber of Commerce and insurance policies for the travellers."

Several agencies have provided an explanation that they are informed briefly with the list that they do not apply because they apply the General Conditions of the Travel made by YUTA, which do not include paragraphs for passenger compensation. While the others do not have the need to use it, because they luckily did not have complaints from their clients, and because their contracts have been precisely signed, with added notes, special requests, etc.

\section{Conclusion}

European travel and package regulations have set high standards for the protection of tourists, and they have made tour operators responsible for defective holiday, physical injuries on the road and during the holiday and damage caused to the property of tourists. Therefore, the tour operators started to make precise contracts in order to protect themselves from the lawsuit for damage compensation, which contributed to the increase in the quality of tourist services in general. However, many directives on travel arrangements do not prescribe the exact amount of compensation for the damage In Germany, that problem has been solved by a comprehensive table, i.e. the Frankfurt table, issued by the state court and which is also applied by Austria and many other European countries.

However, one should bear in mind that the table was created in Germany, that it was arranged according to the European standards, i.e. according to the requirements and needs of their tourists.

In Serbia, the situation is quite different. Domestic travel agencies are mostly managed by the Law on Tourism and General Terms of Travel issued by it. These terms do not prescribe the exact amount of compensation due to the failures during the trip, but only the guidelines are given to the travel agencies for solving the problem as soon as possible.

The contradictory fact is that the arbitration court of the association of travel agencies YUTA consults the Frankfurt table in its arbitration, and that a large number of travel agencies from Serbia, members of the association, are not familiar with the term "Frankfurt table". It is surprising that although dissatisfied tourist in Serbia mostly contact the YUTA for the inconsistent service paid to the travel agency, even $62 \%$ of the surveyed travel agencies claim they do not apply the Table in their business, while $14 \%$ of them apply it partially. Application of the Table in our country would provide better understanding among the travel agencies regarding the obligations from the contract on organized trip, while the quality of the service would be improved, and the tourist, i.e. the consumer, would be much more protected. 


\section{References}

Ateljevic, V. 2010. Consumer protection, what is regulated by the new law. "Agenda", number 2, pages 3-7, Palgo centre, Beograd.

Dragin, A. 2018. Business Ethics and corporate social responsibility in tourism (textbook in the press). Novi Sad: Faculty of Sciences, Department of Geography, Tourism and Hotel Management.

Dragicevic, M. 2010. Responsibility of the tour operator. Sarajevo: Law Faculty of the University of East Sarajevo.

Jurisin, Lj. 2015. Frankfurt List as an example of good practice in the development of business ethics in tourism. Master work. Faculty of Sciences, Department of Geography, Tourism and Hotel Management, Novi Sad.

Simat, K., Dragin, A., Dragicevic, V. 2012. The Institutionalization of Business Ethics of Travel Agencies in Serbia. Turizam 16 (3), 113-123.

Simat, K., Dragin, A. 2012. Business Ethics - the element of successful business of travel agencies. Collection of works of the Department of Geography, Tourism and Hotel Management 41, 297-309.

Cavlek, N. 1998. Tour operators and the world tourism. Zagreb: Golden marketing.

Suleic, M., Dragin, A., Dragicevic, V. 2015. The attitude of a foreign tour operator in Serbia towards tourists in the example of TUI. Turizam 19 (1), 1-12,

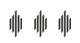

www.advoprax.de/neu/rechtsinformationen/reiserecht

www.glasistre.hr/vijesti/arhiva/kako-naplatiti-propalo-putovanje-341568 www.monitor.hr/ clanci/frankfurtska-tablica-odsteta-nocna-mora-turistickih-zemalja/13925/

www.politika.rs/rubrike/Drustvo/Petnaest-turistickih-agencija-izgubilo-licencu-za-rad. lt.html

www.rechtspraxis.de/frankfurt.htm

www.rts.rs/page/stories/sr/story/125/Dru\%C5\%A1tvo/1363508/ Ko+\%C5\%A1titi+turiste+iz+Srbije.html

www.verbraucherrecht.at/development/typo/test/fileadmin/downloads/ FrankfurterListe/ Frankfurter_Liste_zur_Reisepreisminderung.pdf 